\title{
Impact of Weed Management Interventions on Weed Dynamics, Production Potential and Relative Economics of Direct Seeded Basmati Rice preceded by Wheat
}

\author{
Akhil Verma*, B.C. Sharma, Brij Nandan, Rakesh Kumar and Monika Banotra \\ Sher-e Kashmir University of Agricultural Sciences and Technology, Chatha, Jammu, \\ Jammu and Kashmir 180009, India \\ *Corresponding author
}

Keywords

Direct seeded rice, Weed indices, Grain yield, Economics

Article Info

Accepted:

10 July 2020

Available Online:

10 August 2020

\section{A B S T R A C T}

A field experiment was conducted during kharif 2014 and 2015 at Research Farm of Sher-e-Kashmir University of Agricultural Sciences and Technology, Jammu to study the impact of different weed management practices on weed dynamics, yield attributes, yield and relative economics of direct seeded basmati rice preceded by the weed management interventions applied in the previous crop of wheat. The pre-emergence application of Pendimethalin @ 1.0 kg/ha followed by Bispyribac @ 0.030 $\mathrm{kg} / \mathrm{ha}$ as post-emergence (at $30 \mathrm{DAS}$ ) in direct seeded basmati rice turned out to be the most superior treatment that gave significant control of weeds reducing weed dry weights up to $84.00 \%$ and $86.05 \%$ that in turn increased grain yields to the tune of 58.21 and $63.37 \%$ realizing the highest economic returns of 56098.76 and 35776.19 ₹/ha during kharif seasons of 2014 and 2015, respectively.

\section{Introduction}

Rice (Oryza sativa L.) is grown in about 114 countries and out of which more than 50 countries have an annual production of about 0.1 million tonnes or more (FAO, 2010). The global production of rice during 2017-18 recorded to be 495.4 million tonnes from an area of 162.61 million hectares with an average productivity $4.55 \mathrm{t} / \mathrm{ha}$ (USDA, 2019). In India, this crop plays an important role in country's food security. In the year 2017, rice grain production was 110.15 million tonnes which was realized from 43.19 million hectares of land recording an average grain yield of $2.25 \mathrm{t} / \mathrm{ha}$ (Anonymous, 2017). In Jammu and Kashmir, the production of 0.57 million tonnes rice grain was registered from an area of 0.28 million hectares with an average yield of $2.02 \mathrm{t} / \mathrm{ha}$ (Anonymous, 201617). Among different rice varieties cultivated in the country, aromatic rice cultivars are the 
most unique which are relished by the consumers and fetch higher returns as compared to the other rice types. In Jammu region of the Jammu and Kashmir, the total area under rice is 102.22 thousand hectares (Anonymous, 2016-17), out of which about 62.4 thousand hectares is under different types of basmati cultivars and amongst them Basmati-370 is predominant in the region with an acreage of 53.9 thousand ha recording production of 91 thousand tonnes (Anonymous, 2018). As much as $90 \%$ of rice is produced and consumed in Asia alone. In India, this crop plays an important role in country's food security. Globally, India ranks second among the rice producing countries of the world (Kashid et al., 2015). Among the different varieties of rice cultivated in the country, aromatic rice cultivars i.e. basmati rice are the most unique, due to their flavour they are relished by the consumers and costlier as compared to other varieties and are known for its export earning foreign exchange. It is a unique geographical indicator of the Jammu province of the State, and is known for its export and foreign exchange earnings. Rice is grown by two cultural methods - transplanting and direct seeding. Transplanting rice seedlings on puddled soils is widespread in the irrigated ecosystem. Scarcity and rising cost of labour are the reasons to seek for an alternative technique to transplanting. Basmati rice being a long duration crop needs early establishment to avoid stress periods to prevent lodging and lower seed setting. To achieve this objective direct seeding can be a viable option. Direct seeding offers advantages such as faster and easier planting, reduced labor and drudgery, earlier crop maturity by 7 to 10 days, more efficient use of water, higher tolerance to water deficit, fewer methane emissions, and often higher profits in areas with an assured water supply (Balasubramanian and Hill, 2002).
In direct-seeded rice culture, weeds are the serious constraint. Johnson (1996) reported that weeds in direct-seeded rice adversely affected the yield, quality and cost of production as a result of competition of various growth factors and the yield loss varied from $10 \%$ to complete failure of the crop depending upon the situation. Weeds were reported to reduce rice yields by 12 to $98 \%$, depending on type method of rice establishment. Therefore, in order to achieve higher productivity of wheat and direct seeded rice in rice-wheat cropping system there is an utmost need to evolve concrete weed management strategies for individual crops of wheat and direct seeded rice vis-a-vis for the crop sequence. Keeping the above facts in view an experiment was conducted to assess the impact of weed management practices on weed dynamics and production potential of direct seeded basmati rice preceded by wheat under irrigated subtropics of Jammu region.

\section{Materials and Methods}

A field experiment was conducted during kharif 2014 and 2015 at Research Farm of Sher-e-Kashmir University of Agricultural Sciences and Technology, Jammu. The experimental site was located at $32^{\circ}-40 \mathrm{~N}$ latitude and $74-58^{\circ} \mathrm{E}$ longitude at an altitude of 332 meter above mean sea level in the Shivalik foot hill plains of North-Western Himalayan region. The soil of the experimental field was sandy clay loam in texture, slightly alkaline in reaction, low in available nitrogen $(242.60 \mathrm{~kg} / \mathrm{ha})$, medium in organic carbon $(0.45 \%)$, phosphorous (12.98 $\%)$ and potassium $(154.40 \mathrm{~kg} / \mathrm{ha})$. Initially the experiment started in the previous season of rabi 2013-14, laid out in randomised block design for wheat crop while during kharif season of 2014 the layout was converted into split-plot design for direct seeded basmati rice considering weed management treatments of 
wheat crop as main plot treatments and weed management interventions of direct seeded basmati rice as sub-plot treatments. The weed management treatments of wheat crop comprised of Weedy check; Mechanical weedings-2 at 30 and 60 DAS; Isoproturon @ $1.0 \mathrm{~kg} / \mathrm{ha}+2,4-\mathrm{D} @ 0.500$ 1/ha (PoE); Clodinafop @ $0.060 \mathrm{~kg} / \mathrm{ha} \quad(\mathrm{PoE})$ and Triasulfuron@0.015 kg/ha (PoE) whereas in basmati rice each treatment plot of wheat was split into four sub-plots and the weed management treatments of direct seeded basmati rice consisted of Weedy check; Mechanical weedings-2 at 30 and 60 DAS; Pendimethalin @ $1.0 \quad \mathrm{~kg} / \mathrm{ha} \quad(\mathrm{PE})$; Pendimethalin @ $1.0 \quad \mathrm{~kg} / \mathrm{ha} \quad(\mathrm{PE}) \quad f b$ Bispyribac@0.030 kg/ha (PoE). The variety of basmati rice used in the experiment was Basmati-370. The crop was sown manually in lines $20 \mathrm{~cm}$ apart with seed rate of $40 \mathrm{~kg} / \mathrm{ha}$.

A uniform recommended dose of $\mathrm{N}$ (30 $\mathrm{kg} / \mathrm{ha}), \mathrm{P}_{2} \mathrm{O}_{5}(20 \mathrm{~kg} / \mathrm{ha})$ and $\mathrm{K}_{2} \mathrm{O}(10 \mathrm{~kg} / \mathrm{ha})$ through inorganic sources of nutrients viz., Urea, DAP and MOP was applied uniformly to all the experimental plots along with other cultivation practices as per the respective recommended packages. Out of the recommended doses $50 \%$ of nitrogen in the direct seeded basmati rice crop along with full doses of phosphorus and potassium were applied at the time of sowing as basal dose. The remaining $50 \%$ nitrogen was applied in two equal splits at tillering and panicle initiation stage. Herbicides were applied with the help of Knapsac sprayer fitted with flat fan T-jet nozzle using spray volume of 500 litres/hectare. Pendimethalin @ $1.0 \mathrm{~kg} / \mathrm{ha}$ was applied as pre-emergence within 24 hours of sowing where as in other treatment Pendimethalin @ $1.0 \mathrm{~kg} / \mathrm{ha}$ (pre-emergence) was followed by Bispyribac @ $0.030 \mathrm{~kg} / \mathrm{ha}$ as post-emergence at 30 DAS. Mechanical weedings were done twice 30 DAS and 60 DAS in direct seeded basmati rice with in the crop rows with the help of hand operated wheel hoe. In paddy crop, the irrigations were given as and when hair line cracks were observed on the field to maintain proper moist conditions during active tillering, vegetative and reproductive phases. Plant protection measures were under taken to maintain proper growth and development of the crop.

Three spots each of one square meter were randomly selected by throwing the one square meter quadrant in the net plot. The number of plants from each of the randomly selected spot within the net plot were counted and averaged to express number of plants $/ \mathrm{m}^{2}$. At the time of crop maturity, three crop rows were randomly selected from the net plot area, each measuring one meter row length. The number of panciles within one meter row length was averaged to arrive at the mean number of panicles per row length and finally they were converted into number of panicles $/ \mathrm{m}^{2}$. The total number of grains from the five randomly selected panicles from the tagged plants of sampling rows were counted and averaged to arrive at the number of grains/panicle. The threshed grains obtained from each net plot were weighed separately and finally converted into $\mathrm{q} / \mathrm{ha}$ by multiplying with conversion factor given below:

Yield obtained from net plot $(\mathrm{kg})$ Grain yield $(q / h a)=$

Area of net plot $\left(\mathrm{m}^{2}\right) \times 100$

The determination of weed density was done by standard quadrant method given by Mishra and Mishra (1997). Weed population was recorded from quadrant $(0.5 \mathrm{~m} \times 0.5 \mathrm{~m})$ selected at random in each plot from three places which were expressed on per $\mathrm{m}^{2}$ basis. Weeds collected from area $0.5 \mathrm{~m} \times 0.5 \mathrm{~m}$ area were first sun dried for 2-3 days and then were oven dried at $70^{\circ} \mathrm{C}$ till constant weight was recorded and expressed in $\mathrm{g} / \mathrm{m}^{2}$. The data obtained were subjected to square root transformation $(\sqrt{ } \mathrm{x}+1)$ as wide variations 
existed among the treatments before statistical analysis

\section{Economics}

Relative economics in terms of net returns and $\mathrm{B}: \mathrm{C}$ ratio was worked out on grain and straw yield basis.

\section{Weed population and dry weight}

The major weed species found under weedy conditions throughout the crop growing seasons in direct seeded basmati rice were (Table 1) Cyperus rotondus, Cyperus iria, Cynodon dactylon, Echinochloa colona, and Echinochloa crusgalli amongst narrow leaved weeds (sedges and grasses) and broad leaved weeds included Commolena bengalensis. The weed species found in comparatively smaller numbers were grouped under other weeds that included Convulvulus arvensis, Amaranthus sp., Physalis minima, Celosia argentia, Phyllanthus niruri etc. in both cropping seasons of kharif-2014 and 2015. The relative weed densities of dominant weed species under weedy conditions reveals that narrow leaved weeds were predominant in direct seeded basmati rice crop field in both kharif seasons of 2014 and 2015. Comparison of the individual weed species at crop harvest stage in two years of cropping shows that Cyperus rotondus and Cyperus iria were the major weed species recording the highest relative densities of (31.44 and $29.90 \%)$ and (26.09 and $25.59 \%$ ), respectively. The relative dry weight of weeds shows that narrow leaved weeds were predominant under uninterrupted weedy conditions in the direct seeded basmati rice crop field in both kharif seasons of 2014 and 2015. In terms of relative dry weight / relative dry matter percentage Cyperus rotondus was found to be the most dominant weed species with highest relative weed dry weights of 29.02 and $28.34 \%$ recorded at harvest in two years of kharif cropping under weedy conditions which was followed by Cyperus iria, Commelina benghalensis, Echinochloa colona, Echinochloa crusgalli and Cynodon dactylon in both kharif seasons with corresponding values of relative dry weights obtained under continuous weedy conditions were 25.79 and $25.79 \% ; 15.51$ and $15.54 \% ; 9.05$ and $9.18 \% ; 5.38$ and 6.15 $\% ; 5.84$ and $5.86 \%$, respectively. The weed species that were of lesser numerical significance with regard to dry weights were collectively categorized under other weeds with relative dry weights of 9.41 and $9.14 \%$ recorded at crop harvest stage under weedy check plots during kharif seasons of 2014 and 2015, respectively.

Impact of Weed Management on Weed dynamics in Direct Seeded Rice preceded by Wheat

Perusal of the data presented in Table 2 clearly shows all the weed management interventions in the main plots that were imposed on preceding crop of wheat had nonsignificant influence on the total population and dry weight of weeds in the DS rice crop. Although these weed management treatments had significant influence in minimising weed infestation in the previous crop of wheat. However, after close scrutiny of the data numerical pattern in the total weed count and dry weight was noticed in order from minimum to maximum (increasing order) under the corresponding treatments Isoproturon@1.0 kg/ha +2,4-D @ 0.500 1/ha (PoE); Mechanical weedings twice at 30 and 60 DAS; Triasulfuron@ $0.015 \mathrm{~kg} / \mathrm{ha}(\mathrm{PoE})$; Clodinafop@0.060 kg/ha (PoE) and Weedy check, respectively.

All the weed management treatments applied in the sub plots of the direct seeded basmati rice significantly reduced the count and dry biomass of the weeds compared to weedy check. Application of Pendimethalin @ 1.0 
kg/ha $f b$ Bispyribac @ 0.030 kg/ha (PoE) was significantly superior compared to other treatments in terms of control of weeds with respect to total count and dry biomass, however, sole application of Pendimethalin @ $1.0 \mathrm{~kg} / \mathrm{ha}$ (PE) was second to the best treatment and statistically at par in reducing weed infestation. Both Pendimethalin@1.0 $\mathrm{kg} / \mathrm{ha}(\mathrm{PE})$ and Pendimethalin @ $1.0 \mathrm{~kg} / \mathrm{ha}$ (PE) $f b$ Bispyrebac @ 0.030 kg/ha (PoE) were significantly superior to Mechanical weedings twice at 30 and 60 DAS in decreasing infestation of complex weed flora in direct seeded basmati rice. Similar findings were also reported by Badiyala et al., (2014). Preemergence application of Pendimethalin @ $1.0 \mathrm{~kg} / \mathrm{ha}$ reduced the initially emerging weeds while the latter flushes of weeds were controlled by the sequential application of Bispyrebac@0.030 kg/ha. These results are in concurrence to the studies of Walia et al., (2012); Bhurer et al., (2013) and Prasuna and Rammohan (2015). The application of Pendimethalin @ $1.0 \mathrm{~kg} / \mathrm{ha}$ (PE) provided sufficient control of weeds up to 30 days, however, the small number of weeds that emerged in the subsequent flushes were effectively controlled by the post-emergence application of bispyribac @ $0.030 \mathrm{~kg} / \mathrm{ha}$. The pre-emergence application of pendimethalin @ $1.0 \mathrm{~kg} / \mathrm{ha}$ effectively prohibited the emergence of wide spectrum of weed flora at the very beginning as a consequence the intensity of lately emerged weeds at 30 DAS was not considerably high, in addition to it, the initial advantage gained by the crop over weeds by virtue of early weed control exerted smothering effect on weeds that appeared in the latter stages. Therefore, the plots treated either with alone Pendimethalin @ $1.0 \mathrm{~kg} / \mathrm{ha}$ or Pendimethalin @ $1.0 \mathrm{~kg} / \mathrm{ha}$ (PE) $f b$ Bispyribac@0.030 kg/ha (PoE) in sequence, produced statistically comparable results with regard to reduction in the density and dry matter of total weeds in direct seeded rice crop. These results are akin to the findings of
Khaliq et al., (2011) and Awan et al., (2015).

On the other hand, first mechanical weeding was applied by passing wheel hoe at 30 DAS by that time most of weeds had crossed two to four leaf stage due to which there was considerable increase in density and dry matter of weeds. As a consequence of uninterrupted growth of the weeds for 30 days, the initial momentum gained by the weeds made the weed control by mechanical hoeing very tedious and almost ineffective while the second mechanical weeding at 60 DAS also could not provide a satisfactory control of weeds that emerged subsequently at latter stages. The poor control of weeds by mechanical weedings in direct seeded rice crop might be due to the fact that uneven soil moisture regimes prevailed during the crop period as the crop was direct seeded and intermittent irrigations were applied as and when the hair line cracks developed on the soil surface, due to frequent wetting and drying the soils developed cloddy surface that was unfit for the use of mechanical wheel hoeing. These findings are in line to the observations of Chauhan (2012). Besides, the weeds that emerged with in the crop rows were not removed while the weeds that were uprooted or slashed by the tine of the rotary wheel hoe between crop rows were not properly buried in the soil as a consequence they regenerated from their vegetative propagules left in the field owing to high temperatures and high soil moisture availability that facilitated their regeneration. Similar findings were reported by Auld and Kim (1996), Sudhalakshmi et al., (2005). However, mechanical weedings at 30 and 60 DAS in DS rice significantly reduced the density and dry weight of weeds compared to weedy check.

By and large similar results were obtained in the second year of experimentation with the only difference that all the weed management 
treatments registered marginal reduction of weeds while the weed flora was minutely increased under weedy check plots compared to first year of cropping. This might be due to the less seeds produced by the weeds for the propagation in the succeeding crop since most of the weeds may have been killed before they reach the stage of maturity. Hence, weed population in these treatments with good weed control may be reduced in the succeeding crop. These outcomes corroborate to the findings of Chang (1972). Interaction effects obtained out of the weed management treatments applied to both wheat and rice were found to be non-significant in terms of total density and dry weight of weeds.

\section{Effect on production potential of the crop Yield and yield attributes of direct seeded basmati rice}

The data on yield attributes viz., number of plants $/ \mathrm{m}^{2}$, number of panicles $/ \mathrm{m}^{2}$, number of grains/panicle and test weight and crop yields of direct seeded basmati rice as influenced by different weed management treatments depicted in Tables 3 and 4 clearly indicate that all the weed management treatments in the main plots that were imposed on the previous wheat crop had non-significant influence with regard to crop yields and yield contributing characters in the succeeding rice crop. Although these treatments had shown their impact in enhancing yield and yield attributes in the wheat crop during preceding seaso.

Different weed management interventions applied in direct seeded basmati rice in the present experiment found to cause significant increase in the yield and yield attributes when compared to weedy check. The reduction in weed infestation due to the application of different weed management treatments resulted in the reduction in crop-weed competition which in turn provided higher yield attributes. Amongst different treatments applied for the control of weeds in direct seeded basmati rice significantly highest yield attributes and crop yields were recorded under Pendimethalin @ $1.0 \quad \mathrm{~kg} / \mathrm{ha} \quad(\mathrm{PE}) \quad f b$ Bispyribac@0.030 kg/ha (PoE) which were, however, statistically at par with the alone application of Pendimethalin @ $1.0 \mathrm{~kg} / \mathrm{ha}$ (PE). Application of Pendimethalin @ 1.0 $\mathrm{kg} / \mathrm{ha}$ (PE) $f b$ Bispyribac @ $0.030 \mathrm{~kg} / \mathrm{ha}$ (PoE) recorded higher yield and yield attributes of rice, these results corroborate to the findings of Walia et al., (2008) and Walia et al., (2012). On the other hand, sequential application of Pendimethalin @ $1.0 \mathrm{~kg} / \mathrm{ha}$ (PE) $f b$ Bispyribac @ $0.030 \mathrm{~kg} / \mathrm{ha}$ (PoE) and the sole application of Pendimethalin @ 1.0 $\mathrm{kg} / \mathrm{ha}(\mathrm{PE})$ recorded statistically equivalent yield attributes and crop yields, these results are in conformation to the findings of Khaliq et al., (2011) according to which the application of Pendimethalin $f b$ Bispyribac or alone application of Pendimethalin recorded statistically similar yield attributes, biological yield and comparable grain yields. Similar findings have also been reported by Awan et al., (2015). The pre-emergence application of Pendimethalin@1.0 kg/ha and the sequential application of Pendimethalin @ $1.0 \mathrm{~kg} / \mathrm{ha}$ (PE) which was followed by Bispyrebac @ $0.030 \mathrm{~kg} / \mathrm{ha}(\mathrm{PoE})$ were significantly superior to the treatment of mechanical weedings twice at 30 and 60 DAS in recording higher yields and yield attributes of the rice crop. These results are in concurrence to the findings of Badiyala et al., (2014) and Kumaran et al., (2015).

The reasons attributed to these outcomes are that the pre-emergence application of Pendimethalin@1.0 kg/ha caused significant reduction in the initial flushes of emerging weeds which provided initial advantage to the crop over weeds as weeds pose most severe completion to the crop between 20 to 50 DAS in direct seeded rice as a result the crop-weed 
competition was markedly reduced leading to higher yield attributes that culminated into increased grain and straw yields. The subsequent flushes of weeds were controlled by sequential application of Bispyrebac @ $0.030 \mathrm{~kg} / \mathrm{ha}$ at $30 \mathrm{DAS}$ which further had a supplemental effect on the yield contributing characteristics leading to higher crop yields. The superior control of weeds by the preemergence application of Pendimethalin @ $1.0 \mathrm{~kg} / \mathrm{ha}$ and the sequential application of Pendimethalin @ $1.0 \mathrm{~kg} / \mathrm{ha} \quad(\mathrm{PE}) \quad f b$ Bispyrebac @ 0.030 kg/ha (PoE) caused substantial reduction in crop-weed competition with respect to soil moisture, nutrients, sunlight and space at the very beginning of the crop growth leading to significant improvement in all the growth parameters, yield attributes and yields of the crop. The pre-emergence imposition of Pendimethalin@ @ $1.0 \mathrm{~kg} / \mathrm{ha}$ provided ample suppression of multiple weed flora up to 30 days, however, the smaller number of weeds that appeared in the latter flushes were effectively controlled by the post-emergence application of Bispyrebac @ $0.030 \mathrm{~kg} / \mathrm{ha}$. Although, Bispyrebac @ 0.030 kg/ha applied after Pendimethalin @ $1.0 \mathrm{~kg} / \mathrm{ha}$ as postemergence herbicide recorded enhancement in crop yields and yield attributes numerically but remained statistically at par to the sole application of Pendimethalin @ $1.0 \mathrm{~kg} / \mathrm{ha}$ (PE). On the other hand, critical crop-weed competition period had already commenced in the treatment plots that received mechanical weedings (at 30 and 60 DAS), as a consequence of the competition imposed by the weeds at the very outset the growth of the crop was reduced initially causing an overall reduction in yield and yield attributes besides mechanical weeding in direct seeded rice did not provide satisfactory control of weeds. These results are in agreement with the findings of Kumaran et al., (2015). Similar findings that support the use of herbicides as the most effective means of securing higher rice yields in comparison to mechanical weedings were reported by Cherati et al., (2011) and Kumaran et al., (2015).

Table.1 Relative Weed Density and Relative Weed Dry Weight of different weed species in DS basmati rice at 90 DAS and At harvest

\begin{tabular}{|c|c|c|c|c|c|c|c|c|}
\hline \multicolumn{5}{|c|}{ Relative Weed Density (\%) } & \multicolumn{4}{|c|}{ Relative Weed Dry Weight (\%) } \\
\hline Weed Types & \multicolumn{2}{|c|}{$90 \mathrm{DAS}$} & \multicolumn{2}{|c|}{ At harvest } & \multicolumn{2}{|c|}{$90 \mathrm{DAS}$} & \multicolumn{2}{|c|}{ At harvest } \\
\hline Sedges & $\mathrm{KY}_{1}$ & $\mathrm{KY}_{2}$ & $\mathrm{KY}_{1}$ & $\mathrm{KY}_{2}$ & $\mathrm{KY}_{1}$ & $\mathrm{KY}_{2}$ & $\mathrm{KY}_{1}$ & $\mathrm{KY}_{2}$ \\
\hline Cyperus rotundus & 29.84 & 28.91 & 31.44 & 29.90 & 28.25 & 27.99 & 29.02 & 28.34 \\
\hline Cyperus iria & 25.53 & 24.71 & 26.09 & 25.59 & 25.37 & 25.44 & 25.79 & 25.79 \\
\hline \multicolumn{9}{|l|}{ Grassy Weeds } \\
\hline Cynodon dactylon & 10.99 & 11.24 & 11.62 & 11.82 & 5.87 & 5.99 & 5.84 & 5.86 \\
\hline Echinochloa colonum & 9.03 & 9.17 & 7.21 & 7.43 & 9.44 & 9.52 & 9.05 & 9.18 \\
\hline Echinochloa crussgalli & 7.06 & 7.77 & 6.68 & 7.82 & 6.66 & 6.68 & 5.38 & 6.15 \\
\hline \multicolumn{9}{|l|}{ Broad Leaved } \\
\hline Commelina benghalensis & 11.37 & 11.89 & 11.24 & 11.62 & 15.61 & 15.37 & 15.51 & 15.54 \\
\hline $\begin{array}{l}\text { Other Weeds (Convulvulus } \\
\text { arvensis, Amaranthus sp., } \\
\text { Physalis minima, Celosia } \\
\begin{array}{l}\text { argentia, } \\
\text { niruri) }\end{array}\end{array}$ & 6.18 & 6.32 & 5.72 & 5.82 & 8.81 & 9.00 & 9.41 & 9.14 \\
\hline
\end{tabular}


Table. 2 Effect of weed management practices on weed dynamics of direct seeded basmati rice preceded by wheat

\begin{tabular}{|c|c|c|c|c|}
\hline \multirow[b]{2}{*}{ Treatment } & \multicolumn{2}{|c|}{ Weed density $\left(\mathbf{m}^{2}\right)$} & \multicolumn{2}{|c|}{ Weed dry weight $\left(\mathrm{g} / \mathrm{m}^{2}\right)$} \\
\hline & $\mathrm{KY}_{1} *$ & $\mathbf{K Y}_{2}{ }^{* * *}$ & $\mathrm{KY}_{1}$ & $\mathrm{KY}_{2}$ \\
\hline \multicolumn{5}{|c|}{ Weed management in Wheat } \\
\hline $\mathbf{T}_{1}$ & $\begin{array}{c}11.85 \\
(139.47)\end{array}$ & $\begin{array}{c}12.08 \\
(144.87)\end{array}$ & $\begin{array}{c}10.26 \\
(104.33)\end{array}$ & $\begin{array}{c}10.54 \\
(110.17)\end{array}$ \\
\hline $\mathbf{T}_{2}$ & $\begin{array}{c}10.92 \\
(118.35)\end{array}$ & $\begin{array}{c}10.85 \\
(116.62)\end{array}$ & $\begin{array}{c}9.56 \\
(90.84)\end{array}$ & $\begin{array}{c}9.45 \\
(88.29)\end{array}$ \\
\hline $\mathbf{T}_{\mathbf{3}}$ & $\begin{array}{c}10.68 \\
(113.12)\end{array}$ & $\begin{array}{c}10.65 \\
(112.39)\end{array}$ & $\begin{array}{c}9.33 \\
(86.48)\end{array}$ & $\begin{array}{c}9.26 \\
(84.67)\end{array}$ \\
\hline $\mathbf{T}_{4}$ & $\begin{array}{c}11.56 \\
(132.62)\end{array}$ & $\begin{array}{c}11.39 \\
(128.67)\end{array}$ & $\begin{array}{c}10.08 \\
(100.70)\end{array}$ & $\begin{array}{c}9.95 \\
(98.07)\end{array}$ \\
\hline $\mathbf{T}_{5}$ & $\begin{array}{c}11.24 \\
(125.32)\end{array}$ & $\begin{array}{c}11.15 \\
(123.34)\end{array}$ & $\begin{array}{c}9.70 \\
(93.13)\end{array}$ & $\begin{array}{c}9.64 \\
(91.89)\end{array}$ \\
\hline \multicolumn{5}{|l|}{$\operatorname{SEm}( \pm)$} \\
\hline$L S D(p=0.05)$ & NS & NS & NS & NS \\
\hline \multicolumn{5}{|l|}{ Weed management in rice } \\
\hline $\mathrm{W}_{1}$ & $\begin{array}{c}15.97 \\
(254.09)\end{array}$ & $\begin{array}{c}16.29 \\
(264.78)\end{array}$ & $\begin{array}{c}14.64 \\
(213.34)\end{array}$ & $\begin{array}{c}14.83 \\
(220.62)\end{array}$ \\
\hline $\mathbf{W}_{2}$ & $\begin{array}{c}11.66 \\
(134.92)\end{array}$ & $\begin{array}{c}11.40 \\
(129.03)\end{array}$ & $\begin{array}{c}9.58 \\
(90.72)\end{array}$ & $\begin{array}{c}9.41 \\
(87.55)\end{array}$ \\
\hline $\mathbf{W}_{3}$ & $\begin{array}{c}7.99 \\
(62.90)\end{array}$ & $\begin{array}{c}7.78 \\
(59.57)\end{array}$ & $\begin{array}{c}6.59 \\
(42.41)\end{array}$ & $\begin{array}{c}6.37 \\
(39.57)\end{array}$ \\
\hline $\mathbf{W}_{4}$ & $\begin{array}{c}7.43 \\
(54.14)\end{array}$ & $\begin{array}{c}7.22 \\
(51.13)\end{array}$ & $\begin{array}{c}5.93 \\
(34.12)\end{array}$ & $\begin{array}{c}5.64 \\
(30.77)\end{array}$ \\
\hline $\operatorname{SEm}( \pm)$ & 0.46 & 0.38 & 0.33 & 0.28 \\
\hline$L S D(p=0.05)$ & 1.43 & 1.22 & 0.99 & 0.84 \\
\hline Interaction NS & & & & \\
\hline
\end{tabular}

Figures in the parenthesis are original values subjected to $\sqrt{\mathrm{x}}+1$ square root transformations

$\mathrm{KY}_{1}{ }^{*}$ Kharif- $2014 \mathrm{KY}_{2}^{* *}$ Kharif- 2015

$\mathrm{T}_{1}=$ Weedy Check

$\mathrm{T}_{2}=$ Mechanical Weedings- 2 (30 and 60 DAS)

$\mathrm{T}_{3}=$ Isoproturon @ $1.0 \mathrm{~kg} / \mathrm{ha}+2,4-\mathrm{D} @ 0.500 \mathrm{~L} / \mathrm{ha}$ (Post-emergence)

$\mathrm{T}_{4}=$ Clodinafop $@ 0.060 \mathrm{~kg} / \mathrm{ha}$ (Post-emergence)

$\mathrm{T}_{5}=$ Triasulfuron @ $0.015 \mathrm{~kg} / \mathrm{ha}$ (Post-emergence)

$\mathrm{W}_{1}$ - Weedy check

$\mathrm{W}_{2}$ - Mechanical Weeding-2 (30 and 60 DAS)

$\mathrm{W}_{3}$ - Pendimethalin @ $1.0 \mathrm{~kg} / \mathrm{ha}$ (Pre-emergence)

$\mathrm{W}_{4}$ - Pendimethalin @ $1.0 \mathrm{~kg} / \mathrm{ha}$ (Pre-emergence) $f b$ Bispyribac @0.030 kg/ha (Post emergence) 
Table.2 Effect of weed management practices on yield contributing characteristics of direct seeded basmati rice preceded by wheat

\begin{tabular}{|c|c|c|c|c|c|c|c|c|}
\hline \multirow[t]{2}{*}{ Treatment } & \multicolumn{2}{|c|}{ No. of plants $/ \mathrm{m}^{2}$} & \multicolumn{2}{|c|}{ No. of panicles/plant } & \multicolumn{2}{|c|}{ No. of grains/panicle } & \multicolumn{2}{|c|}{$\begin{array}{c}\text { Test weight } \\
\text { (g) }\end{array}$} \\
\hline & $\mathrm{KY}_{1}$ & $\mathbf{K Y}_{2}$ & $\mathrm{KY}_{1}$ & $\mathrm{KY}_{2}$ & $\mathbf{K Y}_{1}$ & $\mathrm{KY}_{2}$ & $\mathrm{KY}_{1}$ & $\mathbf{K Y}_{2}$ \\
\hline \multicolumn{9}{|c|}{ Weed management in Wheat } \\
\hline$T_{1}$ & 30.08 & 29.83 & 121.38 & 120.55 & 65.50 & 64.48 & 19.38 & 19.34 \\
\hline $\mathbf{T}_{2}$ & 35.18 & 37.30 & 136.17 & 143.82 & 67.80 & 68.81 & 20.52 & 20.90 \\
\hline $\mathbf{T}_{3}$ & 36.42 & 37.96 & 137.62 & 145.16 & 69.13 & 69.13 & 20.71 & 20.97 \\
\hline $\mathbf{T}_{4}$ & 35.05 & 37.00 & 125.33 & 127.63 & 66.17 & 66.18 & 20.07 & 20.24 \\
\hline $\mathbf{T}_{5}$ & 35.11 & 37.24 & 136.08 & 143.05 & 67.40 & 67.41 & 20.17 & 20.86 \\
\hline $\operatorname{SEm}( \pm)$ & 1.81 & 2.57 & 7.71 & 7.07 & 1.74 & 2.26 & 0.45 & 0.47 \\
\hline $\operatorname{LSD}(p=0.05)$ & NS & NS & NS & NS & NS & NS & NS & NS \\
\hline \multicolumn{9}{|c|}{ Weed management in rice } \\
\hline $\mathbf{W}_{1}$ & 27.50 & 27.04 & 107.97 & 106.04 & 56.91 & 52.50 & 18.09 & 17.60 \\
\hline $\mathbf{W}_{2}$ & 30.27 & 33.73 & 120.53 & 128.83 & 63.31 & 63.60 & 19.72 & 20.04 \\
\hline $\mathbf{W}_{3}$ & 38.74 & 40.11 & 145.25 & 152.02 & 73.13 & 75.12 & 21.35 & 22.06 \\
\hline $\mathbf{W}_{4}$ & 40.96 & 42.63 & 151.58 & 157.50 & 75.43 & 77.60 & 21.51 & 22.15 \\
\hline $\operatorname{SEm}( \pm)$ & 0.93 & 0.91 & 2.51 & 2.82 & 0.87 & 1.12 & 0.31 & 0.30 \\
\hline$L S D(p=0.05)$ & 2.88 & 3.19 & 7.55 & 8.46 & 2.66 & 3.39 & 1.09 & 1.05 \\
\hline \multicolumn{9}{|l|}{ Interaction } \\
\hline & & & & & & & & \\
\hline $\begin{array}{l}\mathrm{KY}_{1}{ }^{*} \text { Kharif- } 2014 \\
\mathrm{KY}_{2}{ }^{* * *} \text { Kharif- } 2015\end{array}$ & & & & & & & & \\
\hline
\end{tabular}

$\mathrm{T}_{1}=$ Weedy Check, $\mathrm{T}_{2}=$ Mechanical Weedings- 2 (30 and 60 DAS), $\mathrm{T}_{3}=$ Isoproturon @ 1.0 kg/ha + 2,4-D @ 0.500 L/ha (Post-emergence), $\mathrm{T}_{3}=$ Isoproturon @ $1.0 \mathrm{~kg} / \mathrm{ha}+2,4-\mathrm{D} @ 0.500 \mathrm{~L} / \mathrm{ha}$ (Post-emergence), $\mathrm{T}_{4}=$ Clodinafop @ $0.060 \mathrm{~kg} / \mathrm{ha}$ (Post-emergence), $\mathrm{T}_{5}=$ Triasulfuron @ $0.015 \mathrm{~kg} / \mathrm{ha}$ (Post-emergence); $\mathrm{W}_{1^{-}}$Weedy check, $\mathrm{W}_{2^{-}}$ Mechanical Weeding-2 (30 and 60 DAS), $\mathrm{W}_{3^{-}}$Pendimethalin @ $1.0 \mathrm{~kg} / \mathrm{ha}$ (Pre-emergence), $\mathrm{W}_{4^{-}}$Pendimethalin @ $1.0 \mathrm{~kg} / \mathrm{ha}$ (Pre-emergence) $f b$ Bispyribac @ $0.030 \mathrm{~kg} / \mathrm{ha}$ (Post emergence) 
Table.3 Effect of weed management practices on crop yields and relative economics of direct seeded basmati rice preceded by wheat

\begin{tabular}{|c|c|c|c|c|c|c|c|c|}
\hline \multirow[t]{2}{*}{ Treatment } & \multicolumn{2}{|c|}{ Grain yield (q/ha) } & \multicolumn{2}{|c|}{$\begin{array}{l}\text { Straw yield } \\
\text { (q/ha) }\end{array}$} & \multicolumn{2}{|c|}{ Net returns (₹/ha) } & \multicolumn{2}{|c|}{ B:C ratio } \\
\hline & $K Y_{1}$ & $\mathrm{KY}_{2}$ & $K Y_{1}$ & $K Y_{2}$ & $K Y_{1}$ & $K Y_{2}$ & $K Y_{1}$ & $\mathrm{KY}_{2}$ \\
\hline \multicolumn{9}{|c|}{ Weed management in Wheat } \\
\hline $\mathbf{T}_{1}$ & 16.73 & 17.00 & 27.84 & 26.73 & 33670.29 & 17519.72 & 1.49 & 0.78 \\
\hline $\mathbf{T}_{2}$ & 16.96 & 17.91 & 29.00 & 31.17 & 34522.29 & 19965.72 & 1.52 & 0.89 \\
\hline $\mathbf{T}_{3}$ & 17.23 & 17.95 & 30.00 & 31.53 & 35486.29 & 20089.72 & 1.57 & 0.89 \\
\hline $\mathbf{T}_{4}$ & 16.82 & 17.78 & 28.27 & 29.85 & 34001.29 & 19547.72 & 1.50 & 0.87 \\
\hline $\mathbf{T}_{5}$ & 16.9 & 17.90 & 28.70 & 30.04 & 34300.29 & 19866.72 & 1.51 & 0.88 \\
\hline $\operatorname{SEm}( \pm)$ & 0.37 & 0.98 & 1.23 & 1.89 & - & - & - & - \\
\hline$L S D(p=0.05)$ & NS & NS & NS & NS & - & - & - & - \\
\hline \multicolumn{9}{|c|}{ Weed management in rice } \\
\hline $\mathrm{W}_{1}$ & 9.90 & 9.19 & 17.88 & 17.00 & 12410.62 & 957.05 & 0.59 & 0.05 \\
\hline $\mathbf{W}_{2}$ & 12.22 & 13.35 & 21.41 & 21.65 & 17577.60 & 7964.03 & 0.74 & 0.34 \\
\hline $\mathbf{W}_{3}$ & 21.90 & 23.20 & 36.53 & 40.00 & 51489.19 & 32892.62 & 2.31 & 1.49 \\
\hline $\mathbf{W}_{4}$ & 23.69 & 25.09 & 39.21 & 41.12 & 56098.76 & 35776.19 & 2.37 & 1.52 \\
\hline $\operatorname{SEm}( \pm)$ & 0.47 & 0.59 & 1.00 & 0.96 & - & - & - & - \\
\hline$L S D(p=0.05)$ & 1.83 & 1.91 & 3.01 & 2.88 & - & - & - & - \\
\hline Interaction & NS & & & & & & & \\
\hline $\begin{array}{r}\mathrm{KY}_{1}^{*} \text { Kharif- } \\
2014\end{array}$ & $\mathrm{KY}_{2}^{* * *} \mathrm{Khc}$ & & & & & & & \\
\hline
\end{tabular}

$\mathrm{T}_{1}=$ Weedy Check, $\mathrm{T}_{2}=$ Mechanical Weedings- 2 (30 and $\left.60 \mathrm{DAS}\right), \mathrm{T}_{3}=$ Isoproturon @ 1.0 kg/ha + 2,4-D @ 0.500 L/ha (Post-emergence), $\mathrm{T}_{3}=$ Isoproturon @ $1.0 \mathrm{~kg} / \mathrm{ha}+2,4-\mathrm{D} @ 0.500 \mathrm{~L} / \mathrm{ha}$ (Post-emergence), $\mathrm{T}_{4}=$ Clodinafop @ $0.060 \mathrm{~kg} / \mathrm{ha}$ (Post-emergence), $\mathrm{T}_{5}=$ Triasulfuron @ $0.015 \mathrm{~kg} / \mathrm{ha}$ (Post-emergence); $\mathrm{W}_{1^{-}}$Weedy check, $\mathrm{W}_{2^{-}}$ Mechanical Weeding-2 (30 and 60 DAS), W $3^{-}$Pendimethalin @ $1.0 \mathrm{~kg} / \mathrm{ha}$ (Pre-emergence), $\mathrm{W}_{4^{-}}$Pendimethalin @ $1.0 \mathrm{~kg} / \mathrm{ha}$ (Pre-emergence) $f b$ Bispyribac @ $0.030 \mathrm{~kg} / \mathrm{ha}$ (Post emergence)

Similar outcomes were recorded in the second year of research trial with the only difference that all the weed management treatments registered marginal increase the yield and yield attributes while the reverse trend was noticed in the weedy check plots where a little decline in these parameters were noticed. Interaction effects obtained by the weed management treatments in both wheat and rice with regard to the yield attributes, grain and straw yields were found to be nonsignificant. 


\section{Economics}

All the weed management interventions applied in the direct seeded basmati rice provided higher economic returns over weedy check. Highest net returns of ₹ 56,098.76 and ₹ 35,776.19 per ha were obtained with the application of Pendimethalin @ $1.0 \mathrm{~kg} / \mathrm{ha}$ (PE) $f b$ Bispyribac @ $0.030 \mathrm{~kg} / \mathrm{ha}(\mathrm{PoE})$ which were closely followed by the alone application of Pendimethalin @ $1.0 \mathrm{~kg} / \mathrm{ha}$ (PE) with net returns obtained to the tune of ₹ $51,489.19$ and $₹ 32,892.62$ per ha during kharif seasons of 2014 and 2015, respectively. Similarly, maximum B:C ratios of 2.37 and 1.52 were generated in the treatment Pendimethalin @ $1.0 \mathrm{~kg} / \mathrm{ha} \quad(\mathrm{PE}) \quad f b$ Bispyrebac @ $0.030 \mathrm{~kg} / \mathrm{ha}$ (PoE) while the pre-emergence application of Pendimethalin @ $1.0 \mathrm{~kg} / \mathrm{ha}$ gave comparable $\mathrm{B}: \mathrm{C}$ ratios of 2.31 and 1.49. On the other hand, two mechanical weedings (at 30 and 60 DAS) were found to be far less beneficial in terms of both net returns and $\mathrm{B}: \mathrm{C}$ ratios. This is because of the fact that mechanical weedings with wheel-hoe may not be economically viable due to expensive labor involved in this practice. These results are in line with the studies of Kumaran et al., (2015). Due to the poor crop yields obtained under uninterrupted weedy conditions the lowest net returns and $\mathrm{B}: \mathrm{C}$ ratios were recorded in weedy check. On the other hand, the treatments that provided superior suppression of weeds reduced the competition imposed by weeds on crops leading to better expression of crop growth and yield attributes culminating into higher grain and straw yields that resulted in higher economic gains.

The present investigation concluded that preemergence herbicide application of Pendimethalin @ $1.0 \mathrm{~kg} / \mathrm{ha}$ (PE) in direct seeded basmati rice turned out be the effective option in attaining higher crop yields, weed control and economic returns. However, depending on the severity of weed infestation and higher yield targets sequential application of pre-emergence Pendimethalin @ $1.0 \mathrm{~kg} / \mathrm{ha}$ must be followed by Bispyrebac @ 0.030 $\mathrm{kg} / \mathrm{ha}$ as post-emergence treatment since it offered best weed control for longer periods by eliminating the earlier and later flush of multiple weed flora emerging in direct seeded rice crop field leading to higher crop yields and net returns.

\section{References}

Anonymous. 2016-17a. Digest of Statistics. Directorate of Economics and Statistics. Government of Jammu and Kashmir. Pp- 152

Anonymous. 2016-17b. Digest of Statistics. Directorate of Economics and Statistics. Government of Jammu and Kashmir. Pp- 155-156

Anonymous. 2017. Agricultural Statistics at a Glance 2017. Ministry of Agriculture \& Farmers Welfare Department of Agriculture, Cooperation \& Farmers Welfare. Directorate of Economics \& Statistics. Government of India. Pp-92

Anonymous. 2018. Basmati acreage and yield estimation in Punjab, Haryana, Delhi, Western Uttar Pradesh, Uttrakhand, Himachal Pradesh and parts of Jammu and Kashmir. REPORT-6, Kharif-2018. Basmati Export Foundation, APEDA, New Delhi

Auld B A and Kim K U. 1996. Weed management in Rice. Plant production and protection paper 139, FAO, Rome. p. 27-52

Awan T H , Cruz P C S and Chauchan B S . 2015. Agronomic indices, growth, yield contributing traits and yield of dry seeded rice under varying herbicides. Field Crop Research 177: 15-25.

Badiyala D , Kumar S and Sharma N. 2014. Studies on herbicide combinations for 
control of complex weed flora in directseeded rain fed rice under mid hill conditions of Himachal Pradesh. Biennial Conference of Indian Society of Weed Science on "Emerging Challenges in Weed Management", Directorate of Weed Science Research, Jabalpur, Madhya Pradesh, India, p. 278.,February 15-17,2003.

Balasubramanian V and Hill J E. 2002. Direct seeding of rice in Asia: Emerging isuues and strategic research needs for the $21^{\mathrm{st}}$ century. In: Direct seeding: Research strategies and opportunities. Proceedings of the International workshop on Direct Seeding in Asian Rice Systems, 25-28 January 2000, Bankok, Thailand.

Bhurer K P, Yadav D N , Ladha J K , Thapa R B and Pandey K R .2013. Efficacy of various herbicides to control weeds in dry direct seeded rice (Oryza sativa L.). Global Journal of Biology and Health Sciences 2 (4):205-212.

Chang W L. 1972. Residual effect of herbicides on the succeeding crop of rice. National Science Council (NSC) and the Joint Commission on Rural Reconstruction (JCRR) under the project number 72-All-A-2228 (NSC). p 227-232.

Chauhan B S 2012. Weed management in direct seeded rice systems. Crop and Environmental Sciences Division, IRRI, Philippines. p-14.

Cherati $\mathrm{F}$ E, Bahrami $\mathrm{H}$ and Asakereh A. 2011. Evaluation of traditional, mechanical and chemical weed control methods in rice fields. Australian Journal of Crop Science 5(8):10071013.

FAO, 2010. httpp:/www.fao.org

Kashid M V, Barhate K K and Bodake P S. 2015.Management of weeds in directseeded rice. Indian Journal of Weed Science 47 (2): 110-112.
Khaliq A, Matloo A, Shafiq H M, Ata, Cheema $X \quad Y$ and Wahid A. 2011.Evaluating sequential application of pre and post emergence herbicides in dry seeded fine rice. Pakistan Journal of Weed Science Research 17(2): 111123.

Kumar J, Singh D and Singh B. 2011. Effect of sowing time and weed management practices on direct seeded unpuddled rice (Oryza sativa). Journal of Hill Agriculture, 2 (1): 107-111.

Kumaran S T, Kathiresan G, Murali P, Arthanari, Chinnusamy $\mathrm{C}$ and Kumar S. 2015. Efficacy of new herbicide (Bispyribac sodium 10\% SC) against different weed flora, nutrient uptake in rice and their residual effects on succeeding crop of green gram under zero tillage. Journal of Applied and Natural Science 7 (1): 279 - 285.

Mishra M and Mishra A. 1997. Estimation of integrated pest management index in Jute-A new approach. Indian Journal of Weed Science, 29 (1\&2): 39-42.

Prasuna, J. G. and Rammohan, J. 2015.Effect of weed management practices on growth and yield attributes of aerobic rice. Journal Crop and Weed, 11(1): 229-231

Singh R K, Bohra J S, Srivastava V K and Singh R P. 2008. Effect of diversification of rice-wheat system on weed dynamics in rice. Indian Journal of Weed Science, 40:128-131.

Singh Y, Singh V P, Singh G, Yadav D S, Sinha R, Johnson D E and Mortimer A M. 2011. The implications of land preparation, crop establishment method and weed management on rice yield variation in the rice-wheat system in the Indo-Gangetic plains. Field Crops Research 121: 64-74.

Sudhalakshmi C, Velu Vand Thiyagarajan T M. 2005. Weed management options on dynamics of nitrogen fractions in the 
rhizosphere soil of rice hybrids. Madras Agricultural Journal, 92 (7-9): 444-448.

USDA. 2019. World Agricultural Production. Foreign Agricultural Service. Office of Global Analysis. pp. 15-16

Walia U S, Bhullar M S, Nayyar S and Walia S S. 2008. Control of complex weed flora in dry direct seeded rice (Oryza sativa L.) with pre- and post-emergence herbicides. Indian Journal of Weed Science 40(3\&4): 161-164.

Walia U S, Gill G, Walia S S and Sindhu A S.
2011. Production of direct seeded rice (Oryza sativa) under different plant densities and herbicides in central plains of Punjab. Journal of Crop and Weed 7 (2): $1-5$.

Walia U S, Walia S S, Sindhu A S and Nayyar S. 2012. Bio-efficacy of preand post-emergence herbicides in direct seeded rice in central Punjab. Indian Journal of Weed Science, 44(1): 30-33.

\section{How to cite this article:}

Akhil Verma, B.C. Sharma, Brij Nandan, Rakesh Kumar and Monika Banotra. 2020. Impact of Weed Management Interventions on Weed Dynamics, Production Potential and Relative Economics of Direct Seeded Basmati Rice preceded by Wheat. Int.J.Curr.Microbiol.App.Sci. 9(08): 112-124. doi: https://doi.org/10.20546/ijcmas.2020.908.012 